Mémoires du livre

Studies in Book Culture

\title{
Publications Exchanges in Distribution
}

Retracing the Path of a Book Through a Centralized Medical Exchange

\section{Jennifer J. Connor}

Volume 10, numéro 1, automne 2018

URI : https://id.erudit.org/iderudit/1055411ar

DOI : https://doi.org/10.7202/1055411ar

Aller au sommaire du numéro

\section{Éditeur(s)}

Groupe de recherches et d'études sur le livre au Québec

\section{ISSN}

1920-602X (numérique)

Découvrir la revue

Citer cet article

Connor, J. J. (2018). Publications Exchanges in Distribution: Retracing the Path of a Book Through a Centralized Medical Exchange. Mémoires du livre / Studies in Book Culture, 10(1). https://doi.org/10.7202/1055411ar

\section{Résumé de l'article}

Élargir le concept de propriété pour y inclure la diffusion permet de prendre en compte le parcours d'un livre en dehors des circuits que l'on associe souvent aux études en histoire du livre. Le présent article s'intéresse à la dissémination des livres selon une perspective assez peu courante, soit le rôle de réseaux (à la fois détenteurs provisoires et distributeurs) d'échanges de publications. Ces échanges ouvrent des avenues pour la recherche, comme en témoigne le parcours, au long du $20^{\mathrm{e}}$ siècle, d'un exemplaire d'un livre soumis à un échange continental de publications médicales. Amorcé par le don de l'ouvrage par son auteur à une bibliothèque de médecine d'un comté de la région de Philadelphie, le parcours se poursuit à Toronto, où le livre est expédié puis conservé dans deux bibliothèques de médecine, avant de retourner brièvement à Philadelphie, pour figurer cette fois dans la collection d'un particulier. Il ressort que l'ouvrage en question, The Woman's Medical College of Pennsylvania, sa publication, puis ses pérégrinations transnationales, jettent un éclairage sur le domaine de la médecine en ce qu'ils révèlent diverses tendances ayant marqué au fil des ans l'enseignement de la médecine, l'édition médicale et les échanges entre bibliothèques disciplinaires.

Tous droits réservés (C) Groupe de recherches et d'études sur le livre au Québec, 2019 


\title{
MÉMOIRES DU LIVRE \\ STUDIES IN BOOK CULTURE
}

\section{PUBLICATIONS EXCHANGES IN DISTRIBUTION: \\ Retracing the Path of a Book Through a Centralized Medical Exchange}

\author{
Jennifer J. CONNOR \\ Memorial University of Newfoundland
}

Expanding the concept of ownership to include distributorship allows consideration of a book route that diverges from circuits often associated with book culture studies. In particular, as this article outlines, organized publications exchangeswhich temporarily own and distribute-present opportunities for understanding the spread of books from a different perspective. To demonstrate the research potential of exchanges, the article retraces the path of a single copy of a book over the twentieth century through a continental medical publications exchange, from its donation by the author to a county medical library outside Philadelphia, through its shipment to Toronto where it was housed in two medical libraries, and its brief return to Philadelphia in a personal collection in 2000. As the discussion suggests, this book, The Woman's Medical College of Pennsylvania, its publication and its subsequent transnational peregrinations, spotlight the field of medicine with respect to contemporaneous trends in medical education, publishing, and library movements.

Élargir le concept de propriété pour y inclure la diffusion permet de prendre en compte le parcours d'un livre en dehors des circuits que l'on associe souvent aux études en histoire du livre. Le présent article s'intéresse à la dissémination des livres selon une perspective assez peu courante, soit le rôle de réseaux (à la fois détenteurs provisoires et distributeurs) d'échanges de publications. Ces échanges ouvrent des avenues pour la recherche, comme en témoigne le parcours, au long du $20^{\mathrm{e}}$ siècle, d'un exemplaire d'un livre soumis à un échange continental de publications médicales. Amorcé par le don de l'ouvrage par son auteur à une bibliothèque de médecine d'un comté de la région de Philadelphie, le parcours se poursuit à Toronto, 
où le livre est expédié puis conservé dans deux bibliothèques de médecine, avant de retourner brièvement à Philadelphie, pour figurer cette fois dans la collection d'un particulier. Il ressort que l'ouvrage en question, The Woman's Medical College of Pennsylvania, sa publication, puis ses pérégrinations transnationales, jettent un éclairage sur le domaine de la médecine en ce qu'ils révèlent diverses tendances ayant marqué au fil des ans l'enseignement de la médecine, l'édition médicale et les échanges entre bibliothèques disciplinaires.

The mobility of books has been a persistent feature of their informal distribution among individuals and communities. Whether by chapmen, in street or coffeehouse locales, the exchange of books for profit, cost savings, or leisure occurred in the seventeenth and twenty-first centuries alike. ${ }^{1}$ With the aid of digital technology, book owners today can extend this activity through "book rings" of sequential readers or even trace the global path of their books after they leave them in public places for new readers. ${ }^{2}$ This form of mobility, however, has eluded the gaze of book historians who focus on conventional, often commercial, networks for book distribution or on the movement of books with their original owners. Only recently, too, have they begun to examine the circulation of books between owners and among readers in the context of dissemination through global outposts and travelling collections of donated books. ${ }^{3}$ In book history, library history, and provenance studies, the conveyance of a book tends instead to follow a clear trail that often completes a publications circuit from author to reader as described initially by Robert Darnton. Studies therefore reconstruct the path of a book as a material object in multiple copies from production to readership; ${ }^{4}$ examine the reception and survival of the book's textual content; ${ }^{5}$ or track a single copy through circulating libraries or successive owners. ${ }^{6}$ Darnton intended the design of his book history circuit to be adjustable, and it indisputably provided the catalyst for scholars to adopt, adapt, analyze, reject and extend the concept. ${ }^{7}$ Nevertheless, studies employing his emphasis on people involved in production and distribution, or studies focusing on the written text as it was received and survived among readers, primarily aim to show how ideas circulate through transactions in a commercial or occupational trade, or how they operate once outside the trade. From this view, such studies consider this process as complete, even if continued through transformation or replication. As Leslie Howsam so aptly put it, "In 
[Darnton's] model, the book self-destructs when it has served its purpose of communicating between reader and author."8

In other words, both historical studies and scholars who critique book history models often have either assumed or focused on limited mobility after books reached a final stop in the distribution process, that is the reader-owner, before the books might begin the process again in a new variation. Ownership, no matter what its form, implies engagement: some individual or institution must purchase or acquire a book, whether or not it is then read, acted upon, or transferred to another owner. Reader-ownership also implies stasis or geographic stability of a single copy, at least putatively and for a period of time. This notion is implicit in Harold Love's discussion of print culture as a culture of social relationships, which recognized that the process of distribution is complex and endless: the initial movement from production to consumer might be the first of many, over centuries, to the present time. Yet this observation, and his call for new research, was also cast in economic terms: "The challenge now is to examine not only the contiguous but the mutually remote parts of the cycle of this industrial activity," Love noted, "remembering, again, that it has both its constants and its variables and that some of the variables could be very variable indeed." Mechanisms for book circulation where ownership is transitory, as in the distribution network, perhaps represent one of these remote, loosely connected variables of the model; moreover, they highlight an important distinction between readerowners and distributors. Unlike ownership, distributorship implies indifference: it matters little what commodity is being distributed, even within the context of contraband items. Indeed, modifying the concept of ownership (which implies engagement) to include distributorship (which implies indifference) allows consideration of organized methods for circulation or spread of books among readers, notably the many forms of publications exchanges that emerged by the late nineteenth century. Operating outside the commercial book trade, and sometimes deliberately in opposition to it, these exchanges form part of a larger production-distribution continuum suggested by Howsam as replacement for the discrete activities of publishing and bookselling. ${ }^{10}$

For book history purposes, the centralized exchange entity affords an example of transitory ownership, a temporary placeholder and distribution 
centre for publications that may move from place to place over time. Investigating how such a publications exchange might offer new insights into this aspect of ownership and circulation perhaps calls for a case study, one that views the exchange process from the perspective of the publication that travels through it. Such an approach focuses on the publication as a material object in a different way: by tracing its route through a kind of eddy off the main, conventional book circuit, we might illuminate book history trends from a different angle. Furthermore, tracing an exchange route might foreground, in the terms of transnational historian Simon Macdonald, "how new contexts change the way in which ideas are deployed and understood."11

After exploring the notion of publications exchanges and their history, the following discussion therefore retraces the route of a single copy of a book through an exchange in North America in the twentieth century. Both the book and the exchange are in the realm of medicine. As I suggest, for library historians, medical historians, and book historians, this particular book and the cross-border travel of one copy uniquely reveal both the profession of medicine and its print culture in this period. Its subject matter is neither scientific nor applied medicine, but it is historical in its outline of medical education and the role of women in it. Its context can therefore be described briefly without having to weigh the impact or reception of the ideas the author conveys. Such a book can be viewed from the outside as an artifact more readily, perhaps, than a book that is not a work of institutional history. In this way, the route taken by this book through a continental medical exchange and the reasons for its travels can be seen more clearly: its distribution stops spotlight in particular the demise of private institutional medical libraries in the wake of the university-based health sciences library movement of the later twentieth century, along with the international re-orientation of a publications exchange that serviced them. As this examination will show and explain, every institutional distribution stop on this book's route disappeared by the end of the century.

\section{Publications Exchanges and Their Historical Study}

Formalized exchange of publications and specimens has long been recognized as integral to the development of science since the seventeenth century. Indeed, at a conference in 2015 for the 350th anniversary of the 
world's oldest scientific journal, the Royal Society's Pbilosophical Transactions, the notion of exchange was so well understood by the participants-mostly historians of science who have contributed substantially to contemporary book history-that it ran as a thread throughout the conference and discussions that emphasized exchange as a "gift economy" that "was important in building scientific communities." In his plenary comments, James Secord reiterated several times that the exchange model was important, around the world, that exchange networks in the nineteenth to twentieth centuries in particular were very important, including periodicals exchanges; and in her plenary address, Aileen Fyfe spoke of the gift exchange for Philosophical Transactions, which in the eighteenth century had a free distribution list. By the end of the nineteenth century, the Royal Society's exchange list exceeded 460 institutions, aiding the development of learned society libraries around the world. ${ }^{12}$ The society also had an international exchange of specimens. Such specimen exchanges continue to the present, though not operated by a scientific society (for example, the Specimen Exchange Program of the Agriculture and Agri-Food Canada's National Collection of Vascular Plants ${ }^{13}$ ), yet little research has been done on the means of operation for them, or their publications counterparts, and their evolution.

Over the course of the twentieth century, in fact, international exchanges of scientific publications developed far beyond those operated by individual societies or nation states. A Handbook on contemporary exchange practices appeared that, in its latest edition in 2006, described the framework for exchanges as "a form of international scientific and cultural co-operation" that "promotes the free flow of ideas and scientific ideas among institutes" through a formal contract or free arrangement. Furthermore, the Handbook explained, "Exchange from commercial motives finds no room here. The printed matter for exchange ... may emanate from official or private sources, through the book trade or independently of it." Importantly, the editors posed critical questions about the exchange concept to introduce the intent of the Handbook in providing practical answers, but they are questions that closely align with scholarly study of the topic from the perspective of book history: "Is not a book, in the first place, an object of commercial exchange[,] and the book trade, therefore, the legitimate intermediary between producer and consumer? Has not barter everywhere been replaced by transactions for 
money? Why, especially in the case of books, should the primitive form of transfer be preserved?" 14 In light of the ongoing need to operate an exchange through to the present, and apparently to justify its operation, along with historical discussions that resemble those today for open access and the free circulation of scientific information, this complex subject for science seems ripe for study. ${ }^{15}$

Exchange of publications as an aspect of circulation or distribution is similarly well known yet embedded in book history and library history. The indexes to studies in both fields of scholarship demonstrate its omission, its misplacement, or its relegation to other activities in library management. The study by Adrian Johns, The Nature of the Book, does not index "exchange" despite the inclusion of the latter along with distribution; nor does the Cambridge Companion to the History of the Book index "exchange," although the volume's editor Leslie Howsam identifies its role as part of the cultural transaction of the book. ${ }^{16}$ Another study of the English book trade by James Raven cross-references "exchange" in its index to the Royal Exchange, Exchange Alley, and, in a dead end, to book trade(s): Raven's several discussions of the longstanding practice of exchange of stock among booksellers appears in the index instead under "bookselling." 17 One History of the Book in Canada volume indexes "exchange" only twice, under "Libraries"; and the Encyclopedia of Library History does not include "exchange" in its detailed index, even though it is discussed or mentioned as historically important ways to acquire publications in entries for collection development, interlibrary cooperation, and particular libraries such as the Library of Congress. ${ }^{18}$ So obvious is it to the book trade, and to libraries, that "exchange" seems not to warrant definition, explanation, or separate study. Similarly, the formal "exchange" concept is invisible in recent book history scholarship that seeks specifically to understand the global movement of books. One of the insights gleaned from essays on print culture "beyond the metropolis," the editors inform us, is that print materials often circulated in ways independent of commercial networks and routes established by metropolitan printers, publishers, and booksellers; these ways, including one example of an informal print "exchange," invite historians to rethink circulation in terms of asymmetrical movement suggested by network theory. ${ }^{19}$ This kind of methodological approach, however, may not be optimal 
when studying the somewhat mechanical and impersonal activity of a formalized publications exchange.

This treatment of the exchange concept as understood in book culture studies is ironic, for the notion of exchange is central in the modern turn to transnational history. As Simon Macdonald explained in a review of its scholarship, the core interest of transnationalism rests on circulation, movement, and exchange, an interest he acknowledges will not surprise specialists in book history. Historians have thus studied the reception, negotiation and appropriation of texts in transnational approaches to the history of ideas. ${ }^{20}$ Focusing on "practices of exchange," argued one who analyzed the travels of texts and objects from East to West, overcomes "constructed cultural and paradigmatic boundaries" to illustrate ways that knowledge moved across cultures during the Scientific Revolution. ${ }^{21}$ Furthermore, historians have also studied centralized exchanges, physical places where goods are exchanged in commerce (not unlike the twentiethcentury stock exchange).22 Yet, the notion of exchange in book culture studies remains diffuse and undefined, incorporating commercial and gift transactions alike. Additionally, as Sydney Shep has summarized, book historians who adopt transnational history approaches to investigate circulation of books without borders do point to mobility as the essential characteristic of books. Nevertheless, again, it is their "intrinsic mobility" that transports ideas contained within those books across boundaries of all kinds. Shep's focus in asking how to model the cross-border movement of books, and how to link individual case histories with a larger narrative, seems firmly fixed on the text within the physical publication. ${ }^{23}$ Moreover, her proposed Venn diagram model to advance the field of book history still emphasizes individual texts or actors in its incorporation especially of life histories, life geographies, and the biography of a book. Again, the more impersonal operation of a formalized publications exchange operation to conceptualize "the ways and means by which books travel and transform through space and across time" would seem to fit uncomfortably into the assumptions of Shep's model as presented. ${ }^{24}$

In the specific context of book history scholarship, then, what do we mean by a formal exchange? The concept in this field has typically embraced activities of direct exchange. Within the book trade, for instance, booksellers 
exchanged stock and publishers may have had agreements to swap copies of a printed edition for sheets from another publisher. ${ }^{25}$ After publication, books may be exchanged among individuals and communities. As generally conceded, the concept of formalized publications exchange among communities arose with scientific endeavours, especially among societies and journals. ${ }^{26}$ From the time they began to be published in the seventeenth century with the Philosophical Transactions, scientific journals exchanged issues among themselves to advance scientific knowledge. Societies for other kinds of scholarship subsequently adopted the scientific practices of journal publishing and their exchange; as Johanna Lilja points out, a nineteenthcentury "exchange movement" developed after Finnish learned societies initially believed there were no reliable international commercial distribution channels available. ${ }^{27}$ Indeed, in this period, the custom of journal exchanges in Canada became clear in almost every issue of scientific and medical journals, where journals were listed as received by the Canadian journal office. Similarly, Canadian editors and editorials routinely commented on items in other journals, or reprinted material from them entirely (a sure sign of the declining fortune of a journal was the amount of reprinted content it began to publish from these exchange journals). ${ }^{28}$

Scientific journals might also identify readers or subscribers for exchanges of publications (for example, libraries). From the eighteenth century onwards, however, institutions set up their own publications exchanges. It is this institutional form of exchange that has been little examined by book historians, although it, too, persists in contemporary guises (notably textbook exchanges). ${ }^{29}$ In a brief history of the international exchange of publications, Lilja indicates that Swedish universities first began to organize exchanges, through a consortium called commercium literarium, to expand their library collections for their new research activities. They were followed soon after by universities in Germany. The latter's Akademischer Tauschverein subsequently expanded to institutions from Russia, Scandinavian and European countries, England, the United States, and Australia; in this association's arrangement, publishers and doctoral students were required to provide the exchange with 50 copies of works. ${ }^{30}$

Scientific journals sometimes also identified readers or subscribers for exchanges of specimens (for example, in natural history). ${ }^{31}$ This approach to 
specimen exchange became familiar among trades as well, including printing. As Matthew McLennan Young has indicated, printers in the United States had long exchanged specimens of their work among themselves before the concept of a centralized printers' exchange originated. Their goals were similar to scientists: to advance knowledge in their trade. In 1880, a trade journal in England established this formalized exchange to collect and distribute letterpress and lithographic specimens among printers who subscribed to the Printers' International Specimen Exchange; later, national printers' exchanges emerged in France, Germany, Japan, and the United States. ${ }^{32}$

In the nineteenth century, the need for a centralized publications exchange drew the attention of one man, Alexandre Vattemare, who developed exchange lists for Europe and the United States and successfully handled them for a time. ${ }^{33}$ But, as Simon Macdonald observed, it is (nation) states that provide "key sorting houses for transnational exchange networks and practices." ${ }^{34}$ Over the course of the century, the process of publications exchange was placed in clearinghouses set up by federal institutions. Americans drove this organization of exchanges, and in North America, the impact of the United States in this regard is immeasurable. Although the Library of Congress began an exchange of publications in the 1830s, Nancy E. Gwinn argues that a later partnership between it and the Smithsonian Institution paved the way for a global system: in the 1870s, the Smithsonian's exchange merged scientific material with government documents, creating a model of centralized operation that would be adopted in European countries. ${ }^{35}$ From 1886, international conventions regulating the exchange of publications were held in Brussels; the resulting agreements required each state to establish an exchange bureau to print lists of publications available, distribute the lists to other bureaux, arrange shipments between bureaux, and assume the expenses of shipping. Significantly, while the exchange bureaux could act as "intermediaries between learned bodies and literary and scientific societies" to transmit works for free, they were not permitted to establish such a relationship, "so as to not disturb the freedom and independence of science." 36 By the last quarter of the twentieth century the treaty would be signed by almost forty states. However, the disparity between developed and developing countries became more pronounced as the latter were not able to participate in international exchanges through the establishment of a centre 
or through an adequate number of publications. ${ }^{37}$ Meanwhile, with the advancement of online technologies, exchanges that emerged at other federal institutions would eventually fold: Libraries and Archives Canada, for instance, closed the Canadian Book Exchange Centre in 2008 after a decade of decline in numbers and quality of publications received (by then about 70 per cent of the material received was already being destroyed or recycled). ${ }^{38}$

Among professions, trades, and states, then, national and international exchanges of physical specimens or publications were important activities to advance knowledge in their respective fields of endeavour. The organizational infrastructure for a formalized exchange thus varied according to purpose, whether it was a journal, a society, an institution, or a cooperative of institutions, tradesmen, or states. Libraries in particular widely adopted the exchange concept to improve the collections of publications in donor and recipient libraries by exchanging current literature with other libraries; by acquiring duplicates for exchange from other donations (including bequests); and by actively soliciting duplicates from other libraries-all for free or minimal cost. It was an activity that sometimes drew criticism from publishers, who saw it as limiting the sales of their publications.

It was in this context of a formal institutional exchange to advance knowledge that a continental medical publications exchange formed in Philadelphia in 1898. Through a consortium of libraries, this exchange made possible the donation of a copy of a book to a county society medical library in Pennsylvania: Clara Marshall's The Woman's Medical College of Pennsylvania: An Historical Outline published in Philadelphia in 1897. After the dissolution of the county medical society and its library, this copy moved through the exchange to Toronto in 1924 to another medical society library; the book remained with this Toronto library until 1992 when it, too, was dispersed. The copy was then housed in a hospital library until it was sold as part of the library's deaccessioning only a few years later, in 1998; in 2000, the book moved back to Philadelphia temporarily in a personal collection before returning to Canada a few years later. As explored below, of its transitory institutional owners before 2000, only the publications exchange, operated by the Medical Library Association (MLA), remains. 


\section{Development of a Centralized Medical Publications Exchange}

Medical practitioners adopted the scientific habit of exchanging the latest issues of their journals with other medical journals and exchanging anatomical specimens among their private pathology museums, and they borrowed the library practice of exchanging publications among their medical libraries. Duplicate publications that were acquired through donations and exchange provided the material for ad hoc exchanges with other libraries, especially to fill in gaps in runs of medical journals that recipients actually wanted. Hence, in 1876, Dr. John Shaw Billings of the library of the Surgeon General's Office in Washington advised novice librarians to keep duplicates, for "unless this is done the library will never be a success"; moreover, he told them, "there need be no special haste about the disposal of duplicates, as they increase in value with age." ${ }^{39}$ For this reason, when Dr. F.G. Finley and Margaret R. Charlton were appointed as librarians of the medical library at McGill University in 1895, they immediately sought to receive complimentary copies of medical society transactions and to initiate library exchanges where possible. Letters from many organizations in the United States and Great Britain confirmed their willingness to add McGill's medical library to their mailing list, and several key institutions-notably the Surgeon General's Office and the Smithsonian Institution — entered into routine exchanges of duplicates. ${ }^{40}$ In his new position as Director of the New York Public Library, Billings, too, replied that he would be pleased to receive McGill publications, though his library could not yet send duplicates in return. ${ }^{41}$ By all accounts, these library exchanges were-in the words of the Superintendent of Documents in the Government Printing Office in Washington- "mutually advantageous." 42

These methods of exchange, however, were uneven compared with the central support that was by then afforded to science and scientists by federal institutions. From the middle of the nineteenth century, the Army Medical Museum in Washington, one of the first federally funded scientific institutions in the United States, had exchanged specimens with the Smithsonian, the Department of Agriculture, and medical scientists internationally. ${ }^{43}$ Similarly, the library of the Office of the Surgeon General had its first exchange with the Medical Department of the British Army in 1840; under the later management of John Shaw Billings, the library engaged 
in an extensive campaign to develop its own collection in part through exchange materials. ${ }^{44}$ Wyndham Miles, historian of what became the National Library of Medicine, noted that "Editors seem to have been very helpful in Canada": "John Fulton [of Toronto] published Billings' letter in Canada Lancet and thereby brought donations and exchanges from cooperative Canadians." 45 Without a central depository in Canada, this process was inevitably lopsided, as Fulton remarked two years later: a Canadian historian would eventually "find the most abundant materials, not in his own land, but in the capital of a neighbouring nation." 46

In the 1890s, ophthalmologist and journal editor George M. Gould therefore decided to set up a centralized exchange devoted to medical publications in order to improve the condition of medical libraries throughout the United States. ${ }^{47} \mathrm{He}$ initially used the Journal of the American Medical Association to publish lists of duplicates and items needed that he had received from librarians and physicians via his own office. ${ }^{48}$ (Among the libraries advertising was the McGill University medical library.) After achieving success in this venture, Gould had to think about alternative arrangements to sustain it. Believing that a corporate organization, preferably a government agency, should take over the exchange, he viewed the Surgeon General's Office as ideally suited to act as a clearinghouse for medical literature in much the same way as the Smithsonian Institution served the scientific community. ${ }^{49}$ Rather than negotiate such an arrangement or acquire physical quarters for a clearinghouse, he and other medical leaders took a novel approach by creating an independent society to operate an exchange. The society, later called the Medical Library Association, comprised a consortium of medical libraries to coordinate an exchange of publications for its institutional members and to pressure publishers to donate medical literature to the exchange. At the society's foundational meeting in Philadelphia in 1898, Gould outlined tasks to expand and improve the quality of "public" (as opposed to personal) medical libraries; above all, he sought a systematic exchange of library duplicates so that "volumes not needed by one library may by exchange or purchase find their way to the library heretofore without them." 50 In December 1899, the society began its exchange, which was run for the first six months from the home of its manager in Philadelphia. ${ }^{51}$ Its initial report for these six months indicated modest success, with almost 1,800 publications 
received, about 300 sent to libraries, and 500 periodicals exchanged in individual issues and complete volumes. ${ }^{52}$

The society wrote to presidents of medical societies to seek 50 copies of their society's annual transactions and reports for the exchange, "with the condition that they shall be carefully distributed to public medical libraries in need of them." ${ }^{53}$ Gifts were also sought from publishers, although Gould quickly became annoyed with publishers who rebuffed the request because "every book given or even bought by a library reduces their private sales": this response, Gould claimed in his journal, was "one result of the commercialism of the medical publishing business." ${ }^{4}$ His criticism of publishers led him to address authors directly:

There are not probably half a dozen medical authors who have made or who expect to make a day-laborer's wages for all the time, work, and intellect invested in their books. It is for science and for the profession that they have written. In making contracts, or by special request, they can secure from the publisher 25 or 50 (it should be 50) copies of their books at an inconsiderable expense. Many authors have secured such gifts for the association by renouncing their royalties and securing the volumes from the publishers by gift or at the price of the cost of production.... We appeal to every medical author to secure for the membership libraries of the association such gifts of their publications; it would bring them professional honor and gratitude, would not lessen the sales, and would largely help to raise the medical libraries of the country out of their present pitiable and disgraceful conditions of neglect. ${ }^{55}$

Accordingly, on behalf of the exchange, Gould personally wrote letters to authors. ${ }^{56}$ In the society minutes, Gould acknowledged that several publishers had in fact been generous (including P. Blakiston, Son \& Co., his own publisher), but that there were two classes of publishers: those who ignore the benefit, to the world, by the dissemination of knowledge on the basis of wanting to sell a few books, and those who are "broader minded, more unselfish, or more far sighted." The latter have better business judgement, for, in his view, "the history of the plebification of literature is epitomized by saying that the cheaper and more easily procured have books and papers 
become the more they are demanded and the greater the sales and profits to publishers and writers." 57

The significance of the MLA exchange to early library members, and their delegates, cannot be overstated. The membership application form emphasized the MLA's goals for institutions, from the often repeated objective of the association ("fostering of medical libraries and the maintenance of an exchange of medical literature among its members") to the extra benefits for library members: "current files of a large number of the leading medical journals, society transactions, etc., which are sent free to library members of the Association by the publishers as soon as issued." It described the exchange, with a "vast quantity of valuable medical journals . . . books, pamphlets, reports, etc." donated and distributed "absolutely free" to members- "many thousand dollars' worth of medical literature." 58 Over the course of the twentieth century the society continually adjusted its requirements to allow participation in such free activities to particular kinds of medical libraries (not public libraries, pharmaceutical company libraries, or sectarian medical libraries). Indeed, as I have discussed elsewhere, the development of an exchange of medical literature and the society's institutional membership exclusions based on "science" (not race, the only socially constructed American exclusion for a time) reflect how the field of medicine itself increasingly adopted broader definitions of its knowledge base. ${ }^{59}$

\section{The Life and Times of a Book in a Medical Publications Exchange}

It was in this spirit of exchange that a book was donated by its author to a county medical library in Pennsylvania. The Woman's Medical College of Pennsylvania: An Historical Outline, written by Clara Marshall, was published in Philadelphia by P. Blakiston, Son \& Co. in 1897. 


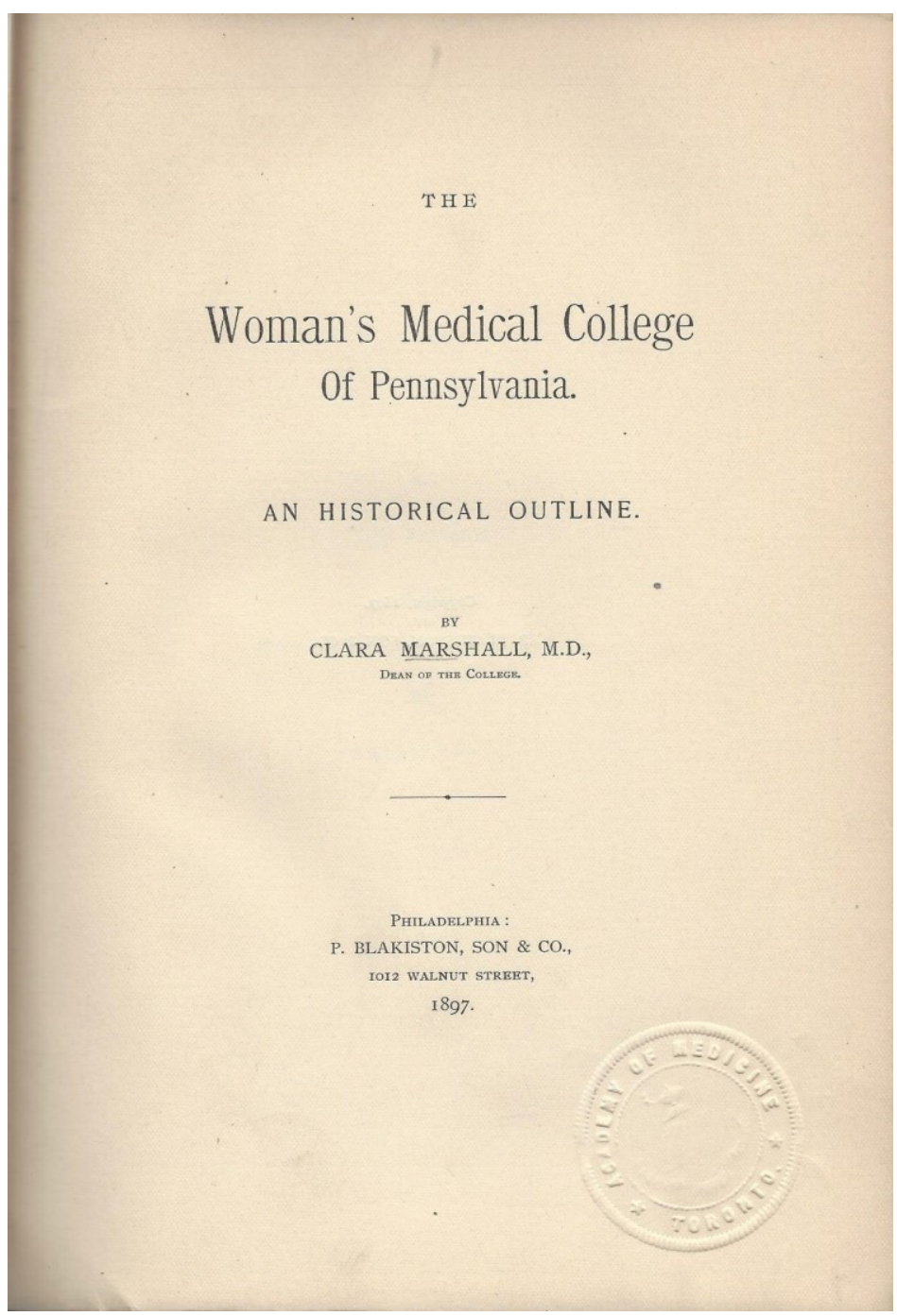

Figure 1: Title page of a book with the library stamp of its last institutional owner in the medical exchange.

The author was well positioned to write a history of the college from its foundation in 1850 as the first institution in the world for the education of women in medicine that awarded the MD degree. Marshall had graduated from the Woman's Medical College of Pennsylvania in 1875, became professor of materia medica there, and then became dean in $1888 .{ }^{60}$ Initially, her account was intended for a collection of essays within a report on women in medicine in the United States prepared for the Chicago World's Congress in 1893 that would be published by the U.S. government. The government's delay in publishing reports from the Congress induced Marshall to publish her work instead as a separate volume. ${ }^{61}$ 
Each part of this book's production spotlights not only the separateness of medical culture from the rest of society, but also the separateness within the practice of medicine that then prevailed. It was not until the twentieth century, in large part owing to its standardized form of university-based education, that medicine became a cohesive profession of practitioners regardless of therapeutic belief, race, or gender. Women had been traditionally denied entry to male-dominated medical schools, and after the Woman's Medical College of Pennsylvania, other colleges were established for women to study medicine. ${ }^{62}$ It was this larger history that Marshall wished to illustrate through emphasis on her college's foundational role in women's medical education. Her book provides an overview of developments, with substantial quotations from original sources. Almost 40 per cent of its 142 pages listed titles of works presented or published in medicine by the college's alumnae; the fact that these works are listed by their medical subject, not by the author, indicates Marshall's intention to demonstrate the calibre of the contributions of these women to the stock of medical knowledge. Indeed, as the college's later historian Steven Peitzman observed, "Marshall's lists of firsts, society memberships, hospital appointments, and especially publications claimed further legitimacy for women doctors and the Woman's Medical College by invoking these emerging standards and values of medical life." 63 Marshall herself served as dean until 1917, covering three critical decades of transformation within the whole of medical education in North America. The Woman's Medical College endured, through constantly escalating standards for medical education; in the late 1960s, however, it became co-educational and dropped the "woman's" from its name-essentially erasing its strong and original mandate. By the 1990s, the college experienced a complex series of further name changes and mergers. ${ }^{64}$

That Marshall chose a local publisher, P. Blakiston, Son, is not surprising; that the publisher would agree to publish still less surprising, for Blakiston was one of several devoted entirely to medicine that arose during the nineteenth century. Indeed, Philadelphia was by then the main centre for a lucrative specialized trade in medical books, not just for the United States, but for the North American continent and beyond. ${ }^{65}$ In 1826, Presley Blakiston joined the Philadelphia firm of Carey and Lea—predecessor to Lea \& Febiger, the world's most successful medical publisher-staying until 1843 when he 
formed a new partnership with Robert Lindsay. Lindsay \& Blakiston then became a prominent medical publisher in its own right, publishing extensive catalogues of books for sale such as one in Canada Lancet in 1873. ${ }^{66}$ Even the year of publication, 1897, was pivotal, for medical leaders who gathered for the historically momentous British Medical Association meeting in Montreal later formed the association in Philadelphia to run a publications exchange to improve medical libraries throughout North America. ${ }^{67}$

As indicated on a bookplate, the author had presented a copy of her book to the Schuylkill County Medical Library.

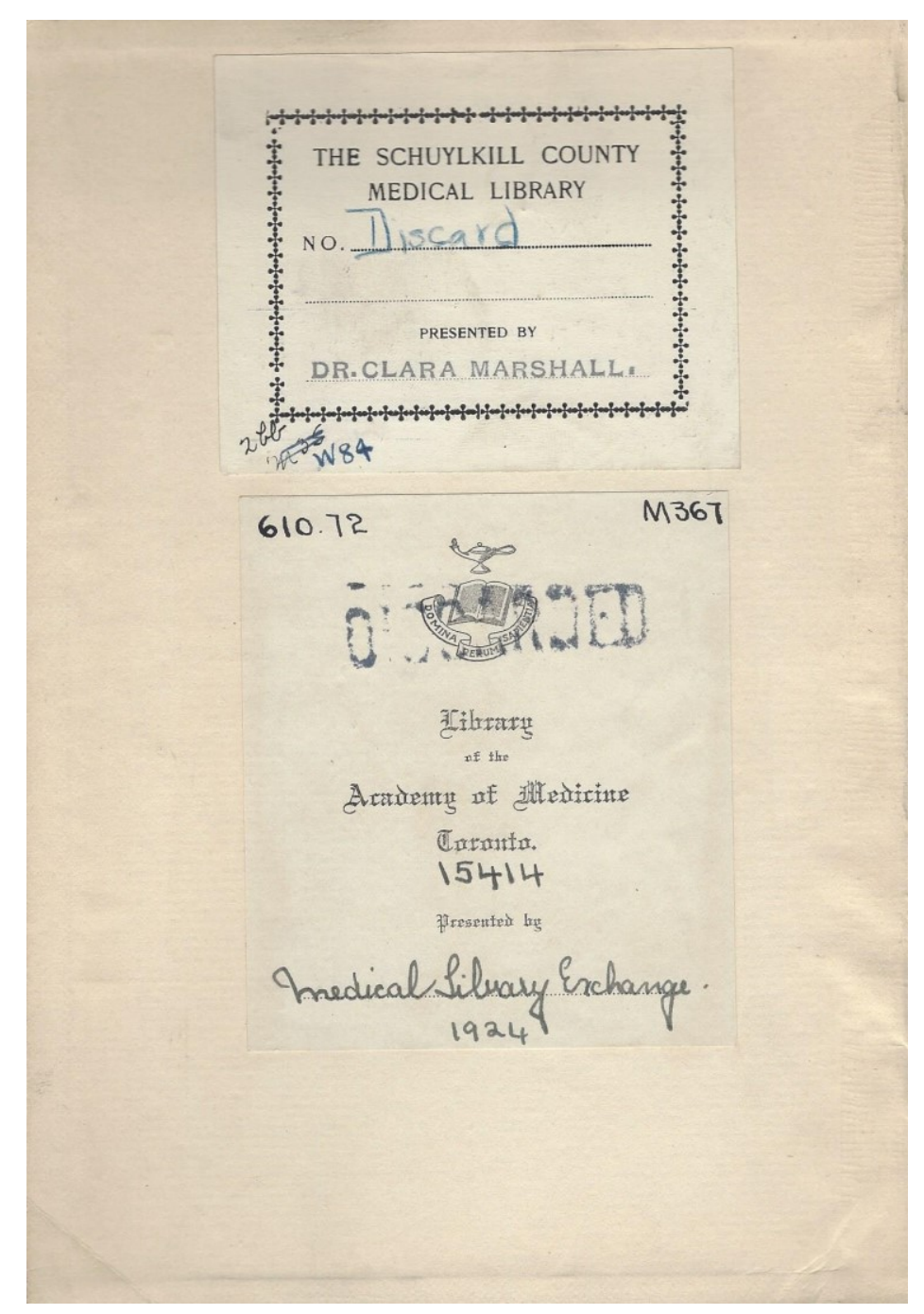

Figure 2: Bookplates showing a book's travels through the Medical Library Association exchange. 
From this act, we can construct a different history through the book, one that embraces both this exchange and the development of medical libraries, as we view the environment from each stop in the distribution process. The book was not donated around the time of its publication, for the county medical library was not established until 1912. At that time, the president of the county medical society called for a committee to consider establishing a medical library; despite the difficulty of raising funds to operate a library on an annual basis, the society soon gained over two dozen fee-paying members, rented a room in a boarding house, and gathered materials from the private collections of two recently deceased physicians and contributions from members. Over the next year, it acquired another private collection, current textbooks from authors, and moved to the gallery of the YMCA building. Reporting on its organization in the Bulletin of the Medical Library Association, Gouverneur Boyer noted that by 1914, the library held 700 bound volumes, 100 unbound volumes of journals, and 1,000 pamphlets, all arranged according to the classification scheme recently designed by Charles Perry Fisher of the College of Physicians of Philadelphia. ${ }^{68}$ The development of such a medical library followed a pattern for small communities around the United States, and in this case, the organizers consciously adopted a plan created by physician C.D. Spivak, which involved constructing a union catalogue of the private libraries of local physicians in Denver. ${ }^{69}$ This plan was developed along with the Denver Public Library and its librarian, John Cotton Dana, a leader in American library activities who would eventually found the Special Libraries Association..$^{70}$ A copy of Spivak's publication about this plan in 1897 had been reprinted by the Denver medical society and sent to all county medical societies in the United States. ${ }^{71}$

This local library in Pennsylvania thus highlights some of the early activity towards organizing medical knowledge and the formation of a medical library movement in the late nineteenth century, including competing approaches. In 1898, Spivak began a small journal, Medical Libraries, to support efforts in these areas, especially to turn this journal into an exchange clearinghouse for subscribers. He recorded a "ready and hearty" response, notably from several library representatives who would later become active in the Medical Library Association for the same reason. ${ }^{72}$ Spivak promised to handle the work of comparing library "want" lists submitted to him and then completing the 
physical transaction between participating libraries, all free of charge. This was significant labour for any individual, let alone for an active, full-time physician, added to which Spivak sought lists from thirty libraries before starting his exchange. Furthermore, this was the only way in which he could claim he had "evolved a new method of exchange which is along the lines of modern civilization - a labor saving device." 73 George Gould had learned to free himself from such an encumbrance after his first exchange list in the Journal of the American Medical Association in 1896 by requesting that libraries communicate direct with each other; even with this improvement, he concluded that the operation required more than individual effort to continue. ${ }^{74}$ Spivak's expectations evidently exceeded his ability to follow through: his exchange does not appear to have materialized and was soon eclipsed by that established officially by Gould through the medical libraries association. ${ }^{75}$

As Boyer also reported in 1914, writers contributed their texts and reprints to the Schuylkill library, and it received material from the exchange of the Medical Library Association. It is possible, then, that one of the authors to respond around this time was Clara Marshall. Clearly, the Schuylkill County Medical Library met the institutional criteria to join the MLA, and it quickly did so in order to benefit from its exchange. However, over the next decade, its membership lapsed, as indicated by its reinstatement in $1924 .{ }^{76} \mathrm{After}$ then, the report of the exchange for 1924 to 1925 shows that the society did not contribute items but received four volumes and eighteen numbers. At the same time, the Toronto Academy of Medicine contributed and received a large number of items. ${ }^{77}$ Of the 45 volumes received, one of them was Marshall's book. The Schuylkill library bookplate shows that the book was discarded from its collection and must have been given to the exchange at some point in order for the Academy of Medicine to identify it as acquired from the MLA exchange. Around this period, both the association and the exchange were experiencing difficulties, with no headquarters or funds for assistants to work on the exchange. The exchange was reorganized over the next year "upon a new basis of operation"; as reported in 1927, "its activities have been increased, its services enlarged and the Exchange reconstructed to such an extent that it has put new life into the organization, reawakened the old esprit of co-operation and elicited a large number of gifts." ${ }^{\prime} 8$ 
This reorganization also elicited discussions of the exchange that outline how it functioned. The original idea, explained its early manager, "was to have a central clearing house but this has been outgrown for many years ..., and the present system is an outgrowth." This system began with a member library sending to the exchange manager a list of duplicate material to donate, a list which may arrive in various formats and styles of citation. The list was edited, mimeographed along with other lists, slipped into a clasp envelope addressed by an addressograph, and mailed to each library member every six weeks. The exchange allowed six weeks for libraries to check these lists and return them to the manager-although distribution of material used to begin within two weeks of the mailing. ${ }^{79}$ The lists were then arranged by size of library and assigned in that order, demonstrating that the large libraries were the first to receive donations - a policy grounded in the larger amount of material they donate and the understanding that they need less material than smaller libraries, but a policy that sometimes raised concerns that there be an "openhearted feeling" among them with respect to the libraries that take from the exchange but do not give back. ${ }^{80}$ Nevertheless, the MLA by-laws continued to stipulate that the largest library be given first choice of the exchange material. ${ }^{81}$ The manager then notified the libraries holding the material, which in turn shipped the material to the designated libraries.

Most material destined for American libraries was sent by express, "marked Books, Value Not More Than Ten Dollars," but "Send everything to Canada by mail," the exchange manager cautioned in 1928, "Express is held up at the Border." 82 By 1928, a depository was maintained separately in New York for excess material of libraries in the eastern United States; this depository created its own list for the exchange manager, with material being distributed from New York. ${ }^{83}$ In 1932, the MLA provided a list of specific directions for participating in its exchange. To avoid problematic delivery and to use the cheapest shipping costs, it reminded members to include the librarian's name or the word "library" in the address, and to mark any package under 100 pounds as " 3 rd Class Express Collect, value not over \$10.00." Shipments that were large or sent long distances used freight, collect, billing the recipient library for packing and drayage. Instructions for Canada became more explicit and emphatic:

In sending express to Canadian libraries, or from Canada to the United States, please get a customs invoice from your local express 
office, fill out and mail it to the receiving library, as some libraries have difficulty getting packages through the customs without this invoice. This particularly applies to outside ports such as Montreal, Toronto, New York, Brooklyn, Boston, New Orleans, San Francisco.

As well, the MLA asked libraries to list material again if they were not able to distribute it within a year after it was offered and assigned; to acknowledge all packages to the donor and not the exchange; and to keep statistics of material sent out for their own purposes. On this last note, the exchange managers were glad to know that "material is changing hands," but were not yet in a position to make use of the statistics themselves. ${ }^{84}$

Nothing else is known about the Schuylkill County Medical Library after this time, and it is believed that it probably did not remain active soon after its reinstatement as MLA member. It is tempting to suppose that Clara Marshall's book formed part of the reinstatement by demonstrating library activity in its donation to the exchange, perhaps an easy donation because it was not a work about current medical knowledge. The book travelled that year to one of the larger medical library members, the Academy of Medicine, Toronto, as indicated by the activity of this library in the MLA exchange. The development of this society library in Ontario differed substantially from that of the county library in Pennsylvania, for it was conceived from the start as a provincial institution, one that would facilitate advancement in medical knowledge and not merely act as a repository or resource for medical neophytes. Canada did not have a major collection of medical literature, save for the medical library at McGill University, and such a collection was critical for physicians to write new works of synthesis. In 1887, physicians in Ontario therefore planned a large medical reference library in Toronto to redress the ongoing problem; as one observed,

It is almost impossible to write an article or paper on any medical subject, which will be of lasting value, unless the writer has access to a large reference library. Authors of papers are frequently compelled to go to Philadelphia or New York to consult medical works which cannot be procured here..$^{85}$

Once organized under the name "Ontario Medical Library Association," the library began to receive both financial support and large donations of books. ${ }^{86}$ At first housed by the College of Physicians and Surgeons of Ontario, the 
library eventually amalgamated with three Toronto medical societies in 1907 to form the Academy of Medicine of Toronto. This academy's medical library then became and remained the largest in Ontario until the 1940s, when it was surpassed by the University of Toronto, and until 1992 it maintained a large collection of nineteenth-century Canadian medical works (especially journals). ${ }^{87}$ Coincidentally, the year that Marshall's book was added to its library, the academy began formal plans for expanded quarters, though it did not move to a new building until twenty years later. Its library acquisitions and donations of duplicate materials through the MLA exchange continued as a routine part of its activities. 88

The Academy of Medicine, Toronto and its library reflected trends in health science libraries after the Second World War. The advent of "big science" in massive biomedical funding and research in the post-war era, with consequent financial support of academic institutions, the loss of authority in the medical profession, the societal emphasis on "health," and the technological revolution in computers all led to significant changes in the numbers and kinds of health sciences libraries in North America. As medical school and hospital libraries increased in numbers, all other kinds decreased, indicating the rise of the health sciences centre, where the majority of medical practitioners work and are most likely to use a medical library collection. As Susan Crawford explained, since independent local societies (sometimes called academies) had smaller libraries than nearby institutional libraries, they found it "increasingly difficult to maintain an adequate general medical library based on the principle of serving all physicians within a geographic area." 89 Three surveys of American health science libraries in the 1970s thus showed that state and county medical societies continued to decline in numbers-by almost 60 per cent over this decade alone. ${ }^{90}$ Despite their elite status in league with similar large collections in the United States that are still active today (notably the College of Physicians of Philadelphia and the New York Academy of Medicine), both the library and the museum of the Academy of Medicine, Toronto, met the same fate. After the society increasingly lost support among the medical community, over the decade between 1992 and 2002, its collections were temporarily housed and dispersed among many different institutions in Ontario. Initially, the important rare book collection was assumed by the Fisher Rare Book Library of the University of Toronto, and the rest of the collection-along with most of the museum's artifacts- 
was assumed by the Toronto Hospital. ${ }^{91}$ Within only a few years, the hospital library began to deaccession many of these items, selling them for inconsequential amounts in order to clear the stacks in preparation for the building's demolition. They included early textbooks in medicine, important for their historical value but not to an active collection of current medical literature, and similar historical volumes as that of Clara Marshall. ${ }^{22}$

\section{The Publications Exchange: Window on Book Distribution and Ownership}

Clara Marshall's book and the travels of one copy are perhaps unique in casting light on trends in book history and medical history alike. It was a book of its time and place. Its focus on women reflected a time when separate schools met their need for education in medicine. Its publisher similarly reflected a period of specialism in medicine in the book trade, one that was then centralized in Philadelphia. Its ownership by society libraries reflects their role in a medical library movement at the end of the nineteenth century. That movement led to the formation of a publications exchange, and a new organizational structure to run it-another medical society for institutional members. Immediately after the Second World War, all of these activities would change dramatically. With one exception, every institutional stop along this individual book's route has disappeared, a process of assimilation and transformation that reflects twentieth-century trends in medicine itself. The woman's medical college was absorbed into a mainstream medical school. The specialty publisher was bought by succeeding general publishers to McGraw-Hill, ${ }^{93}$ just as independent medical publishers generally were absorbed into multinational publishing conglomerates. Local medical societies and their libraries went into decline with the rise of university-based research and health science centres; and the Medical Library Association transformed into a society for librarians and their professionalization. Only the MLA exchange remains. However, the rise in biomedical funding and research in the post-Second World War era, combined with many other global events, helped to turn this North American society and its exchange into an international endeavour.

In this latter activity, the MLA exchange was not alone. The Army Medical Library/National Library of Medicine exchange waxed and waned through 
the twentieth century. By the First World War, the library no longer required exchange for others to obtain duplicates from its large collection; after the Second World War, it engaged in significant international exchanges, acquiring materials that generally were unavailable commercially. These international exchanges were redoubled in the 1960s, especially for materials in languages other than English; by then, the library sent publications to 900 institutions in 80 countries, receiving many items in return that were otherwise difficult to obtain. ${ }^{94}$

Nevertheless, the experience of Marshall's book suggests a possible approach for studying the centralized exchange entity and its operationalization in a transnational context. Though the book's content may have attracted few readers or scholars-perhaps because it did not attract such attention-its physical movement as an object through such an exchange, across an international border, also serves to illustrate a different kind of ownership in the context of book history. The ownership by a centralized exchange was impersonal and transitory. In this way, the book's route suggests that the MLA exchange was not troubled by the same questions of ownership encountered in earlier exchange mechanisms; for example, as Lilja explains about the exchange of European universities, since the initiative usually came from professors and the distribution was initially done by universities, material obtained through this exchange was sometimes considered to be the private property of the professors. ${ }^{95}$ Once they entered the MLA exchange, publications were owned temporarily by the exchange before they were distributed to new institutional owners. Moreover, this single copy did not travel with people, or particular owners, as understood in conventional or comparative studies of distribution networks and provenance; rather, it moved through distribution stops and institutional owners that each became temporary. Its mobility derived almost entirely from external forces in the history of medical libraries and medical institutions that nudged or propelled it along. The exchange clearly enabled this copy to survive, but apparently without intervention by readers. Were it not for bookplates, the retracing of this single copy would not be possible, and it would have remained invisible among the unnamed volumes transferred through the exchange to institutional owners. The last transfer of ownership that passed the copy into a personal collection was serendipitous, and in this examination the book has 
become even more of a physical artifact than an object of textual communication.

The focus on this copy as a physical object has enabled a clearer view of its movement beyond the pivotal production stop described by Adrian Johns, the "threshold of sites devoted to public access and exchange" once the printed book has arrived in the warehouse. As Johns maintained, "Pursuing the trail further proves a task of no little complexity, as the processes and practices of distribution, exchange, sale, and use were manifold." Although most books "had to pass through some sort of retail site," 96 study of their alternative routes through exchange mechanisms - as suggested here with the MLA exchange-offers perhaps similarly divergent ways of viewing their readership and reception. Study of publications exchanges may uncover more about what Gould (somewhat presciently) called the "plebification of literature." It is doubtful that they ever functioned so transparently to consumers as to increase sales or subscriptions of new publications, as he envisaged. Their own closure in recent times owing to unusable materials being deposited (likely along with lack of space to store them) also suggests that other factors contribute to the success or lack of success of a particular exchange. Regardless, for book historians, such a methodological approach serves to re-conceptualize a book as its author's "float through posterity" (a view held by Canadian physician William Osler) ${ }^{97}$ to explore instead the float's ports of call.

Jennifer J. Connor is Professor of Medical Humanities in the Faculty of Medicine, cross-appointed to the Department of History, and affiliated with the Department of Gender Studies, Memorial University of Newfoundland. In 2015 she received both the Marie Tremaine Medal and the Watters-Morley Prize of the Bibliographical Society of Canada in recognition of her historical and bibliographical scholarship that focuses on medical book culture. She is a former editor of the Papers of the Bibliographical Society of Canada, and long ago, former co-editor of the Canadian Bulletin of Medical History. 


\section{Notes}

${ }^{1}$ Adrian Johns, The Nature of the Book: Print and Knowledge in the Making (Chicago: University of Chicago Press, 1998), 153-58. Today, the Little Free Library provides (often beautifully constructed) containers of books for neighbours to share (see http://littlefreelibrary.org).

${ }^{2}$ For example, BookCrossing is a global book club where books are left in public places, swapped on the website (http://www.bookcrossing.com), or transferred by arrangement through "book rings."

${ }^{3}$ James J. Connolly, Patrick Collier, Frank Felsenstein, Kenneth R. Hall, and Robert G. Hall, eds., Print Culture Histories Beyond the Metropolis (Toronto: University of Toronto Press, 2016); Jennifer J. Connor, “'Dispensing Good Books and Literature' to Coastal Communities: The Role of the Grenfell Mission in Newfoundland and Labrador, 1890s1940," Newfoundland and Labrador Studies 32, no. 2 (2017): 362-98.

${ }^{4}$ Robert Darnton, "What Is the History of Books?", Daedalus 111 (Summer 1982): 65-83; Thomas R. Adams and Nicolas Barker, "A New Model for the Study of the Book," in $A$ Potencie of Life: Books in Society, ed. Nicolas Barker (London: British Library, 1993), 5-43. See also C. Deirdre Phelps, "Where's the Book? The Text in the Development of Literary Sociology," TEXT: An Interdisciplinary Annual of Textual Studies 9 (1996): 63-92. Fuller discussion is afforded in Leslie Howsam, Old Books and New Histories: An Orientation to Studies in Book and Print Culture (Toronto: University of Toronto Press, 2006).

${ }^{5}$ Kevin Sharpe, Reading Revolutions: The Politics of Reading in Early Modern England (New Haven, CT: Yale University Press, 2000); H.J. Jackson, Marginalia: Readers Writing in Books (New Haven, CT: Yale University Press, 2002); James A. Secord, Victorian Sensation: The Extraordinary Publication, Reception, and Secret Authorship of Vestiges of the Natural History of Creation (Chicago: University of Chicago Press, 2000).

${ }^{6}$ David Pearson, Provenance Research in Book. History: A Handbook (London: British Library, 1994); Judith A. Overmier and Lilli Sentz, "Medical Rare Book Provenance," Bulletin of the Medical Library Association 75, no. 1 (1987): 14-18.

7 Adams and Barker, "A New Model"; Phelps, "Where's the Book?"; Robert Darnton, “'What is the History of Books?' Revisited," Modern Intellectual History 4, no. 3 (2007): 495508; Leslie Howsam, Past into Print: The Publishing of History in Britain, 1850-1950 (London: British Library and University of Toronto, 2009), 3-5; Sydney Shep, "Books in Global Perspectives," in The Cambridge Companion to the History of the Book, ed. Leslie Howsam (Cambridge: Cambridge University Press, 2015), 64-67.

${ }^{8}$ Howsam, Old Books, 37.

9 Harold Love, "Early Modern Print Culture: Assessing the Models," in The Book History Reader, $2^{\text {nd }}$ ed., ed. David Finkelstein and Alistair McCleery (London: Routledge, 2006), 81.

${ }^{10}$ Howsam, Old Books, 62-63.

${ }^{11}$ Simon Macdonald, “Transnational History: A Review of Past and Present Scholarship"

Vol. 10, n 1 | Fall 2018

"Adventure: From Travel Technology to Print Media" 
(January 2013), 12, University College London, Centre for Transnational History, https://www.ucl.ac.uk/centre-transnational-

history/objectives/simon macdonald tns review.

${ }^{12}$ Jim Secord, in "The History of Scientific Publishing: The State of the Art," Plenary with Adrian Johns and Aileen Fyfe, Publish or Perish? The Past, Present and Future of the Scientific Periodical Conference, Royal Society, London, March 2015; Aileen Fyfe, "Journals, Learned Societies and Money: Pbilosophical Transactions, ca. 1750-1900," Royal Society Notes and Records 69 (September 2015): 288. For more information see Aileen Fyfe, Julie McDougall-Waters, and Noah Moxham, "350 Years of Scientific Periodicals," Royal Society Notes and Records 69 (September 2015): 227-39.

13 Agriculture and Agri-Food Canada, "Specimen Exchange Program of the Agriculture and Agri-Food Canada National Collection of Vascular Plants,"

http://www.agr.gc.ca/eng/science-and-innovation/research-centres-and-

collections/national-collection-of-vascular-plants-dao/specimen-exchange-program-of-

the-agriculture-and-agri-food-canada-national-collection-of-vascular-

plants $/$ ?id $=1255525344567$.

14 "Background," in Handbook on the International Exchange of Publications, ed. Kirsti Ekonen, Païvi Paloposki, and Pentti Vattulainen (München: K.G. Saur, 2006), 11.

15 Johanna Lilja, "Developing the International Distribution of Humanities Studies in Finland: The Exchange of Publications of Two Learned Societies in 1831-1914," Library History 23 (September 2007): 220.

16 Johns, Nature of the Book, 108, 153; Leslie Howsam, "The Study of Book History," in The Cambridge Companion to the History of the Book, ed. Leslie Howsam (Cambridge: Cambridge University Press, 2015), 4.

${ }_{17}$ James Raven, The Business of Books: Booksellers and the English Book Trade, 1450-1850 (New Haven, CT: Yale University Press, 2007).

${ }^{18}$ Yvan Lamonde, Patricia Lockhart Fleming, and Fiona A. Black, eds., History of the Book in Canada Volume Two 1840-1918 (Toronto: University of Toronto Press, 2005); Anne L. Buchanan, et al., "Collection Development," in Encyclopedia of Library History, ed. Wayne A. Wiegand and Donald G. Davis, Jr. (New York: Garland, 1994), 153-64; Elizabeth I. Hanson, "Interlibrary Cooperation," in Encyclopedia of Library History, ed. Wiegand and Davis Jr., 285-87.

${ }_{19}$ Patrick Collier and James J. Connolly, "Print Culture Histories beyond the Metropolis: An Introduction," in Print Culture Histories Beyond the Metropolis, ed. Connolly, Collier, Felsenstein, Hall, and Hall, 12-15.

${ }^{20}$ Simon MacDonald, "Transnational History," 9, 12. See also Mae M. Ngai, "Promises and Perils of Transnational History" (December 2012),

https://www.historians.org/publications-and-directories/perspectives-on-

history/december-2012/the-future-of-the-discipline/promises-and-perils-of-transnationalhistory.

Vol. 10, n 1 | Fall 2018

"Adventure: From Travel Technology to Print Media" 
${ }^{21}$ Avner Ben-Zaken, Cross-Cultural Scientific Exchanges in the Eastern Mediterranean, 1560-1660 (Baltimore: Johns Hopkins University Press, 2010), 4.

${ }^{22}$ Harold J. Cook, Matters of Exchange: Commerce, Medicine, and Science in the Dutch Golden Age (New Haven, CT: Yale University Press, 2007).

${ }^{23}$ Shep, "Books in Global Perspectives," 61, 54.

${ }^{24}$ Shep, "Books in Global Perspectives," 66.

${ }^{25}$ Raven, Business of Books, 59, 89, 95, 97, 226-28, 238, 299, 301, 355; Darnton, "What is the History of Books?' Revisited," 500.

${ }^{26}$ Sarah S. Gibson, "Scientific Societies and Exchange: A Facet of the History of Scientific Communication," Journal of Library History 17, no. 2 (1982): 144-63; Bertrum H. MacDonald, "Crossing Borders: The Smithsonian Institution and Nineteenth-century Diffusion of Scientific Information Between the United States and Canada," in Science in Print: Essays on the History of Science and the Culture of Print, ed. Rima D. Apple, Gregory J. Downey, and Stephen L. Vaughn (Madison: University of Wisconsin Press, 2012), 87-106.

${ }^{27}$ Lilja, "Developing," 219.

${ }^{28}$ For example, see "Journals Received in Exchange," Medical Chronicle, or, Montreal Journal of Medicine \& Surgery 1 (August 1853): 95; "Our Exchanges," Medical Chronicle, or, Montreal Journal of Medicine \& Surgery 1 (September 1853): 127; "New Journals," Medical Chronicle, or, Montreal Journal of Medicine \& Surgery 1 (October 1853): 156. For discussion of editors' engagement with other journals, see Jennifer J. Connor, "Publisher Ownership, Physician Management: Canadian Medical Journals in the Victorian Era," Victorian Periodicals Review 34, no. 4 (2010): 388-428; Bertrum H. MacDonald and Jennifer J. Connor, "Science, Technology, and Medicine: Constructing Authorship," in History of the Book in Canada Volume Two 1840-1918, ed. Lamonde, Fleming, and Black, 178-79.

${ }^{29}$ See, for example, Canadian School Book Exchange, https://www.csbe.net/content/donations2.aspx.

${ }^{30}$ Johanna Lilja, "History of the International Exchange of Publications," in Handbook on the International Exchange of Publications, ed. Ekonen, Paloposki, and Vattulainen, 52. Both the publication of the Handbook and its sponsoring organization, the International Federation of Library Associations (IFLA), are beyond the scope of this discussion, which focuses mainly on the period up to the early twentieth century. IFLA was founded in 1927, and the Handbook was first published in 1950.

${ }^{31}$ Yet in science, exchange often involves far more than books, journals, and specimens. Here, as historians of science note, a key motivation is intellectual reciprocity; in the "gift economy" of science, reciprocity means sharing not just journals, specimens and laboratory materials but also authorship: the latter is accorded to scientists, including medical professionals, for contributions toward the scientific research and publication that may not involve writing in the conventional sense understood by the word "author." See, for example, MacDonald and Jennifer Connor, "Science, Technology, and Medicine," 177-86; Mario Biagioli and Peter Galison, eds., Scientific Authorship: Credit and Intellectual Property in

Vol. 10, n 1 | Fall 2018

"Adventure: From Travel Technology to Print Media" 
Science (New York: Routledge, 2003); Anne Hudson Jones and Faith McLellan, eds., Ethical Issues in Biomedical Publication (Baltimore: Johns Hopkins University Press, 2000). A related concept of reciprocity is the gift of specimens to museums, which usually meant that the donor in exchange received recognition, fame, and lasting memory: see, for example, Samuel J.M.M. Alberti, Morbid Curiosities: Medical Museums in Nineteenth-Century Britain (Oxford: Oxford University Press, 2011), 84-87.

32 Matthew McLennan Young, The Rise and Fall of the Printers' International Specimen Exchange (New Castle, DE: Oak Knoll Press, 2012).

33 Lilja, "History," 53-55; Nancy E. Gwinn, "The Library of Congress, the Smithsonian Institution, and the Global Exchange of Government Documents, 1834-1889," Libraries and the Cultural Record 45, no.1 (2010): 107-11.

${ }^{34}$ Simon Macdonald, “Transnational History,” 13.

35 Gwinn, "Library of Congress," 107.

${ }^{36}$ Lilja, "History," 56.

${ }^{37}$ Lilja, "History," 63-65.

${ }^{38}$ Libraries and Archives Canada, "Closure of the Canadian Book Exchange Centre: A Program of Library and Archives Canada," https://www.collectionscanada.gc.ca/whatsnew/013-330-e.html. See also the archived web page for the Canadian Book Exchange Centre: https://www.collectionscanada.gc.ca/cbec-ccel/index-e.html.

${ }^{39}$ J.S. Billings, "Medical Libraries in the United States," in Public Libraries in the United States of America: Their History, Condition, and Management. Special Report. Department of the Interior, Bureau of Education. Part I (Washington: Government Printing Office, 1876), 180.

${ }^{40} \mathrm{McG}$ ill University, Osler Library of the History of Medicine (hereafter MUOL), Acc. 544, Medical Library Archives, Files 38/65/0/1-5, General correspondence 1896-1900; "Library," in Calendar of the Faculty of Medicine, McGill University 1896-97, 73.

${ }^{41}$ MUOL, Medical Library Archives, File 38/65/0/1 1896, John S. Billings to M.R. Charlton, 28 April 1896.

42 MUOL, Medical Library Archives, File 38/65/0/1 1896, F.A. Crandall to M.R. Charlton, 21 November 1896.

${ }^{43}$ Michael G. Rhode and James T.H. Connor, "AA Repository for Bottled Monsters and Medical Curiosities': The Evolution of the Army Medical Museum," in Defining Memory: Local Museums and the Construction of History in America's Changing Communities, $2^{\text {nd }}$ ed., ed. Amy K. Levin and Joshua G. Adair (Lanham, MD: Rowman \& Littlefield, 2017), 181-82; J.T.H. Connor and Michael G. Rhode, "The United States Army Medical Museum as International Scientific Resource," paper presented at the session "Knowledge On the Go: North American Institutions and the International Exchange of Scientific Text and Specimens, 1850s-1950s," Fifth British-North American Joint Meeting of the British Society for the

Vol. 10, n 1 | Fall 2018

"Adventure: From Travel Technology to Print Media" 
History of Science, Canadian Society for the History and Philosophy of Science, and History of Science Society, Halifax, Nova Scotia, August 2004.

${ }^{44}$ Wyndham D. Miles, A History of the National Library of Medicine: The Nation's Treasury of Medical Knowledge (Bethesda, MD: National Library of Medicine, 1982), 8, ch. 4, 79-81.

${ }^{45}$ Miles, History of the National Library of Medicine, 54.

46 “A National Medical Library,” Canada Lancet 6 (1874): 235-36.

${ }^{47}$ The following discussion of George Gould, the medical library movement, and the MLA exchange derives from my earlier studies: Jennifer Connor, Guardians of Medical Knowledge: The Genesis of the Medical Library Association (Lanham, MD: Rowman \& Littlefield, Scarecrow Press, 2000); Jennifer J. Connor, "Writing Medicine: George M. Gould and Medical Print Culture in Progressive America," in Science in Print, ed. Apple, Downey, and Vaughn, 10729; and Jennifer J. Connor, "Only for 'purely scientific' Institutions: The Medical Library Association's Exchange, 1898-1950s," Journal of the Medical Library Association 99, no. 2 (2011): 118-26.

48 "The Organization and Support of Public Medical Libraries," JAMA 29 (October 9, 1897): 748; "Library Wants and Supplies," JAMA 27 (November 21, 1896): 1114-15.

49 John Y. Cole, "Storehouses and Workshops: American Libraries and the Uses of Knowledge," in The Organization of Knowledge in Modern America, 1860-1920, ed. Alexandra Oleson and John Voss (Baltimore: Johns Hopkins University Press, 1979), 379; Nancy E. Gwinn, "Smithsonian Institution Libraries, Washington, D.C., USA," in Encyclopedia of Library History, ed. Wiegand and Davis, Jr. (New York: Garland, 1994), 580.

50 "Association of Medical Librarians. Minutes of First Meeting," reprinted in Albert Tracy Huntington, "The Association of Medical Librarians: Past, Present, and Future," Medical Library and Historical Journal 5 (1907): 114. In 1898, the same year that the association for libraries formed, the idea for a similar association arose for medical museums and the exchange of their specimens. It was not until 1906, however, that the International Association of Medical Museums formed and set up the Bureau for International Exchange of specimens, initially through McGill University; the exchange moved to the Army Medical Museum in 1922. See "The International Association of Medical Museums," Science, N.S. 28 (December 11, 1908): 832; “The McGill Medical Museum and the International Association of Medical Museums,"

https://www.mcgill.ca/medicalmuseum/exhibits/warbones/international; International Academy of Pathology, "Early Years," http://www.iapcentral.org/home/history/earlyvears; and Bulletin of the International Association of Medical Museums.

51 [Marcia] C. Noyes, "Report of the Exchange," Bulletin of the Medical Library Association 14 (April 1925): 48.

52 National Library of Medicine, History of Medicine Division, Modern Manuscripts Collection (hereafter NLMHMD), Medical Library Association Archives, Early Correspondence, First Annual Report of the Library "Exchange."

Vol. 10, n 1 | Fall 2018

"Adventure: From Travel Technology to Print Media" 
${ }^{53}$ NLMHMD, Medical Library Association Archives, Early Correspondence, Secretary's Report of the Third Annual Meeting of the Association of Medical Librarians, 2, and "To the President of the [blank]," [form letter, n.d.].

54 “The Association of Medical Librarians," Philadelpbia Medical Journal 5 (March 24, 1900): [645].

55 “To Disseminate Medical Literature and Encourage Public Medical Libraries," Philadelphia Medical Journal 5 (March 31, 1900): [697].

56 NLMHMD, Medical Library Association Archives, Early Correspondence, George M. Gould to Doctor Buck, 14 December 1899 [form letter].

${ }^{57}$ NLMHMD, Medical Library Association Archives, Early Correspondence, Secretary's Report of the Third Annual Meeting of the Association of Medical Librarians, 2.

58 NLMHMD, Medical Library Association Archives 1898-2002, Series 22: Early Correspondence, 2002-33/13, Applications for Membership.

${ }^{59}$ For more information, see Jennifer Connor, "Only for 'purely scientific' Institutions."

${ }^{60}$ Steven J. Peitzman, A New and Untried Course: Woman's Medical College and Medical College of Pennsylvania, 1850-1998 (New Brunswick, NJ: Rutgers University Press, 2000), 68-72.

61 Clara Marshall, The Woman's Medical College of Pennsylvania: An Historical Outline (Philadelphia: P. Blakiston, Son, 1897), "Preface."

62 Mary Roth Walsh, Doctors Wanted, No Women Need Apply: Sexual Barriers in the Medical Profession, 1835-1975 (New Haven, CT: Yale University Press, 1977). Walsh examines the first medical college to be established for women in Boston in 1848. This college had no building and difficulty sustaining itself, so much so that shortly after the Philadelphia college was founded in 1850 it proposed a merger with the Boston school with faculty offering the program in alternating sessions in the two cities (53).

${ }^{63}$ Peitzman, New and Untried Course, 71.

${ }^{64}$ One merger was with another separate form of medical school, the internationally respected college of homoeopathic medicine, Hahnemann, until the late 1990s when the medical school was taken under the management of Drexel University: see Peitzman, New and Untried Course, 222-53.

${ }^{65}$ Jennifer J. Connor, "Stalwart Giants: Medical Cosmopolitanism, Canadian Authorship, and American Publishers," Book History 12 (2009): 210-39.

66 "Catalogue of New Works and New Editions Recently Published by Lindsay \& Blakiston Together with a Condensed List of All Their Publications, April 1873," Canada Lancet 5 (July 1873).

${ }^{67}$ Jennifer Connor, Guardians of Medical Knowledge, 47-51. 
${ }^{68}$ There were no classification schemes specifically for medicine prior to the late nineteenth century: see Miles, History of the National Library of Medicine, 92, 116, 170, 293-94; Jennifer Connor, Guardians of Medical Knowledge, 31. On the development of five universal classification systems from the late nineteenth century, see Francis L. Miksa, "Classification," in Encyclopedia of Library History, ed. Wiegand and Davis, Jr., 144-53.

${ }^{69}$ Gouverneur H. Boyer, "The Organization of the Schuylkill County Medical Library," Bulletin of the Medical Library Association 4 (April 1915): 55-59.

70 Norman D. Stevens, "Dana, John Cotton (1856-1929)," Dictionary of American Library Biography, ed. Bohdan S. Wynar (Littleton, CO: Libraries Unlimited, 1978), 115-20.

${ }^{71}$ C.D. Spivak, "How Every Town May Secure a Medical Library," Medical News 71, no. 4 (October 2, 1897): 444; "Statistics of Medical Libraries," JAMA 30 (January 8, 1898): 111. For more information, see Jennifer Connor, Guardians of Medical Knowledge, 24-25.

72 “The Medical Libraries Exchange,” Medical Libraries 2, no. 3 (May-June 1899): 104.

73 “The Medical Libraries Exchange,” Medical Libraries 2, no. 4 (July-August 1899): 107.

74 "Notice to Physicians and Librarians of Public Medical Libraries," JAMA 28 (January 30, 1897): 236.

75 This discussion derives from my Guardians of Medical Knowledge, 62-63; for fuller information, see ch. 3 .

76 "Minutes of the Twenty-seventh Meeting of the Medical Library Association," Bulletin of the Medical Library Association 14 (July 1924): 2.

77 "Report of the Exchange of the Medical Library Association, June 1924-May 1925," Bulletin of the Medical Library Association 15 (October 1925): 21.

78 "Report of the Executive Committee," Bulletin of the Medical Library Association 17 (July 1927): 39 .

79 “The Work of the Exchange," Bulletin of the Medical Library Association 13 (April 1925): 36.

80 "Minutes of the Twenty-eighth Meeting of the Medical Library Association," Bulletin of the Medical Library Association 15 (October 1925): 17.

81 James F. Ballard, "Medical Library Exchange," Bulletin of the Medical Library Association 17 (October 1928): 36-37; "Medical Library Exchange," Bulletin of the Medical Library Association 17 (October 1928): 26.

82 "Medical Library Exchange," Bulletin of the Medical Library Association 17 (October 1928): $23-24$.

83 Ballard, "Medical Library Exchange," 37.

Vol. 10, n 1 | Fall 2018

"Adventure: From Travel Technology to Print Media" 
84 "Medical Library Association Exchange," Bulletin of the Medical Library Association 20 (January 1932): 117-18.

85 “The Ontario Medical Library Association,” Canadian Practitioner 12 (1887): 219.

86 "The Ontario Medical Library Association," Canadian Practitioner 12 (1887): 251, 373; H.B. Anderson, "A Brief History of the Development of the Library and the Academy Since Its Inception," Bulletin of the Academy of Medicine, Toronto 5 (May 1932): 34-39; Oskar Klotz, "The Library," Bulletin of the Academy of Medicine, Toronto 5 (May 1932): 49-52; Geo. F. Boyer, "Our Inheritance," Bulletin of the Academy of Medicine, Toronto 20 (1946): 30-37; E. Stanley Ryerson, "Events Leading to the Formation of an Academy," Bulletin of the Academy of Medicine, Toronto 20 (1947): 231-38; H.B. Anderson, "History of the Library of the Academy of Medicine, Toronto," Bulletin of the Academy of Medicine, Toronto 20, no. 1 (1946): 239-52; Norman B. Gwyn, "Sir William Osler's Contributions to the Library of the Academy of Medicine, Toronto," Bulletin of the Academy of Medicine, Toronto 20 (1947): 266-71.

${ }^{87}$ Geo. Boyer, “Our Inheritance,” 36.

88 M. Edna M. Poole, "Annual Report of the Librarian," Bulletin of the Academy of Medicine, Toronto 19 (1945): 167; 20 (1947): 173.

${ }^{89}$ Susan Crawford, "Health Sciences Libraries of Professional Societies, Voluntary Health Organizations, and Foundations," Bulletin of the Medical Library Association 60, no. 2 Suppl. (1972): 42. See also Susan Crawford, Carol Michel, and Conrad Waligorski, "The Contemporary Medical Society Library," Bulletin of the Medical Library Association 53, no. 2 (1965): 178-95.

${ }^{90}$ Susan Crawford, "Health Science Libraries in the United States: I. Overview of the PostWorld War II Years," Bulletin of the Medical Library Association 71, no. 1 (1983): 17.

91 Philip Oldfield and Richard Landon, Ars Medica: Medical illustration through the ages. An exbibition to commemorate the seventieth anniversary of the founding of Associated Medical Services (Toronto: Thomas Fisher Rare Book Library, 2006), 14. A full history of these collections is beyond the scope of this discussion. However, by 2002, remaining artifacts moved to a museum in Kingston, Ontario. In 2014 the academy held no meetings, lost its charitable organization status, retained some items in storage at another hospital in north Toronto, and any of its few remaining funds are used for an annual fundraising dinner for this hospital. See Coalition of Canadian Health-Care Museums and Archives, Newsletter 3 (Fall 2002); Toronto Academy of Medicine, "Past and Future of Toronto Academy of Medicine," 7 February 2014, http://torontomedicalmeetings.blogspot.com/.

${ }^{92}$ It was at this time that the book entered my personal collection, purchased for about $\$ 2.00$. The book travelled with me to Philadelphia in 2000, and then back to Canada (St. John's, Newfoundland) in 2004.

${ }^{93}$ Jennifer Connor, “Stalwart Giants,” 220.

${ }^{94}$ Miles, History of the National Library of Medicine, 205-6, 318-19, 449.

${ }^{95}$ Lilja, "History," 52.

Vol. 10, n 1 | Fall 2018

"Adventure: From Travel Technology to Print Media" 
${ }^{96}$ Johns, Nature of the Book, 108.

${ }^{97}$ William Osler, quoted in John B. Blake, "Billings and Before: Nineteenth Century Medical Bibliography," in Centenary of Index Medicus, 1879-1979, ed. John B. Blake (Bethesda, MD: National Library of Medicine, 1980), 39. Writing in 1913 about John Shaw Billings, Osler observed specifically that "there is no better float through posterity than to be the author of a good bibliography."

\section{Bibliography}

\section{Primary and Unpublished Sources}

Agriculture and Agri-Food Canada. "Specimen Exchange Program of the Agriculture and Agri-Food Canada National Collection of Vascular Plants." http://www.agr.gc.ca/eng/science-and-innovation/research-centres-andcollections/national-collection-of-vascular-plants-dao/specimen-exchangeprogram-of-the-agriculture-and-agri-food-canada-national-collection-of-vascularplants/?id=1255525344567.

“The Association of Medical Librarians." Philadelphia Medical Journal 5 (March 24, 1900): [645].

"Association of Medical Librarians. Minutes of First Meeting." In Albert Tracy Huntington. "The Association of Medical Librarians: Past, Present, and Future." Medical Library and Historical Journal 5 (1907): 111-23.

Ballard, James F. "Medical Library Exchange." Bulletin of the Medical Library Association 17 (October 1928): 36-37.

Billings, J.S. "Medical Libraries in the United States." In Public Libraries in the United States of America: Their History, Condition, and Management. Special Report. Department of the Interior, Bureau of Education. Part I, 171-82. Washington: Government Printing Office, 1876.

BookCrossing. http://www.bookcrossing.com/.

Boyer, Gouverneur H. "The Organization of the Schuylkill County Medical Library." Bulletin of the Medical Library Association 4 (April 1915): 55-59.

Bulletin of the International Association of Medical Museums.

Calendar of the Faculty of Medicine, McGill University 1896-97.

Canadian Book Exchange Centre. https://www.collectionscanada.gc.ca/cbecccel/index-e.html. 
Canadian School Book Exchange.

https://www.csbe.net/content/donations2.aspx.

"Catalogue of New Works and New Editions Recently Published by Lindsay \& Blakiston Together with a Condensed List of All Their Publications, April 1873." Canada Lancet 5 (July 1873).

Coalition of Canadian Health-Care Museums and Archives. Newsletter 3 (Fall 2002).

Connor, J.T.H., and Michael G. Rhode. "The United States Army Medical Museum as International Scientific Resource." In session "Knowledge On the Go: North American Institutions and the International Exchange of Scientific Text and Specimens, 1850s-1950s," Fifth British-North American Joint Meeting of the British Society for the History of Science, Canadian Society for the History and Philosophy of Science, and History of Science Society, Halifax, Nova Scotia, August 2004.

"To Disseminate Medical Literature and Encourage Public Medical Libraries." Philadelphia Medical Journal 5 (March 31, 1900): [697].

International Academy of Pathology. "Early Years." http://www.iapcentral.org/home/history/early-years.

"The International Association of Medical Museums." Science, N.S. 28 (December 11, 1908): 832.

"Journals Received in Exchange." Medical Chronicle, or, Montreal Journal of Medicine \& Surgery 1 (August 1853): 95.

Klotz, Oskar. "The Library." Bulletin of the Academy of Medicine, Toronto 5 (May 1932): 49-52.

Libraries and Archives Canada. "Closure of the Canadian Book Exchange Centre: A Program of Library and Archives Canada." https://www.collectionscanada.gc.ca/whats-new/013-330-e.html.

“Library Wants and Supplies.” JAMA 27 (November 21, 1896): 1114-15.

Little Free Library. http://littlefreelibrary.org.

Marshall, Clara. The Woman's Medical College of Pennsylvania: An Historical Outline. Philadelphia: P. Blakiston, Son, 1897. 
"The McGill Medical Museum and the International Association of Medical Museums."

https://www.mcgill.ca/medicalmuseum/exhibits/warbones/international.

McGill University, Montreal. Osler Library of the History of Medicine. Acc. 544, Medical Library Archives.

“The Medical Libraries Exchange.” Medical Libraries 2, no. 3 (May-June 1899): 104.

“The Medical Libraries Exchange.” Medical Libraries 2, no. 4 (July-August 1899): 107.

"Medical Library Exchange." Bulletin of the Medical Library Association 17 (October 1928): 23-26.

"Medical Library Association Exchange." Bulletin of the Medical Library Association 20 (January 1932): 117-18.

"Minutes of the Twenty-eighth Meeting of the Medical Library Association." Bulletin of the Medical Library Association 15 (October 1925): 17-22.

"Minutes of the Twenty-seventh Meeting of the Medical Library Association." Bulletin of the Medical Library Association 14 (July 1924): 1-9.

National Library of Medicine. History of Medicine Division. Modern Manuscripts Collection. Medical Library Association Archives.

“A National Medical Library.” Canada Lancet 6 (1874): 235-36.

"New Journals." Medical Chronicle, or, Montreal Journal of Medicine \& Surgery 1 (October 1853): 156.

"Notice to Physicians and Librarians of Public Medical Libraries." JAMA 28 (January 30, 1897): 236.

Noyes, [Marcia] C. "Report of the Exchange." Bulletin of the Medical Library Association 14 (April 1925): 48-49.

Oldfield, Philip, and Richard Landon. Ars Medica: Medical Illustration through the Ages. An Exhibition to Commemorate the Seventieth Anniversary of the Founding of Associated Medical Services. Toronto: Thomas Fisher Rare Book Library, 2006.

“The Ontario Medical Library Association." Canadian Practitioner 12 (1887): 219, 251, 373.

"The Organization and Support of Public Medical Libraries." JAMA 29 (October 9, 1897): 748. 
"Our Exchanges." Medical Chronicle, or, Montreal Journal of Medicine \& Surgery 1 (September 1853): 127.

Poole, M. Edna M. "Annual Report of the Librarian." Bulletin of the Academy of Medicine, Toronto 19 (1945): 167.

Poole, M. Edna M. "Annual Report of the Librarian." Bulletin of the Academy of Medicine, Toronto 20 (1947): 173.

"Report of the Executive Committee." Bulletin of the Medical Library Association 17 (July 1927): 39-42.

"Report of the Exchange of the Medical Library Association, June, 1924-May, 1925." Bulletin of the Medical Library Association 15 (October 1925): 21-22.

Secord, James. In "The History of Scientific Publishing: The State of the Art." Plenary with Adrian Johns and Aileen Fyfe. Publish or Perish? The Past, Present and Future of the Scientific Periodical Conference, Royal Society, London, March 2015.

Spivak, C.D. "How Every Town May Secure a Medical Library." Medical News 71, no. 4 (October 2, 1897): 444.

“Statistics of Medical Libraries.” JAMA 30 (January 8, 1898): 111.

Toronto Academy of Medicine. "Past and Future of Toronto Academy of Medicine.” 7 February 2014. http://torontomedicalmeetings.blogspot.com/.

"The Work of the Exchange." Bulletin of the Medical Library Association 13 (April 1925): 36-37.

\section{Secondary Sources}

Adams, Thomas R., and Nicolas Barker. "A New Model for the Study of the Book." In A Potencie of Life: Books in Society, edited by Nicolas Barker, 5-43. London: British Library, 1993.

Alberti, Samuel J.M.M. Morbid Curiosities: Medical Museums in Nineteenth-Century Britain. Oxford: Oxford University Press, 2011.

Anderson, H.B. "A Brief History of the Development of the Library and the Academy Since Its Inception." Bulletin of the Academy of Medicine, Toronto 5 (May 1932): 34-39.

. "History of the Library of the Academy of Medicine, Toronto." Bulletin of the Academy of Medicine, Toronto 20, no. 1 (1946): 239-52. 
"Background." In Handbook on the International Exchange of Publications, edited by Kirsti Ekonen, Païvi Paloposki, and Pentti Vattulainen, 11-12. München: K.G. Saur, 2006.

Ben-Zaken, Avner. Cross-Cultural Scientific Exchanges in the Eastern Mediterranean, 1560 1660. Baltimore: Johns Hopkins University Press, 2010.

Biagioli, Mario, and Peter Galison, eds. Scientific Authorship: Credit and Intellectual Property in Science. New York: Routledge, 2003.

Blake, John B. "Billings and Before: Nineteenth Century Medical Bibliography." In Centenary of Index Medicus, 1879-1979, edited by John B. Blake, 31-52. Bethesda, MD: National Library of Medicine, 1980.

Boyer, Geo. F. "Our Inheritance.” Bulletin of the Academy of Medicine, Toronto 20 (1946): $30-37$.

Buchanan, Anne L., et al. "Collection Development." In Encyclopedia of Library History, edited by Wayne A. Wiegand and Donald G. Davis, Jr., 153-64. New York: Garland, 1994.

Cole, John Y. "Storehouses and Workshops: American Libraries and the Uses of Knowledge." In The Organization of Knowledge in Modern America, 1860-1920, edited by Alexandra Oleson and John Voss, 364-85. Baltimore: Johns Hopkins University Press, 1979.

Connolly, James J., Patrick Collier, Frank Felsenstein, Kenneth R. Hall, and Robert G. Hall, eds., Print Culture Histories Beyond the Metropolis. Toronto: University of Toronto Press, 2016.

Connor, Jennifer. Guardians of Medical Knowledge: The Genesis of the Medical Library Association. Lanham, MD: Rowman \& Littlefield, Scarecrow Press, 2000.

Connor, Jennifer J. "'Dispensing Good Books and Literature' to Coastal Communities: The Role of the Grenfell Mission in Newfoundland and Labrador, 1890s-1940." Newfoundland and Labrador Studies 32, no. 2 (2017): 362-98.

- "'Only for 'purely scientific' Institutions: The Medical Library Association's Exchange, 1898-1950s." Journal of the Medical Library Association 99, no. 2 (2011): 118-26.

_. "Publisher Ownership, Physician Management: Canadian Medical Journals in the Victorian Era." Victorian Periodicals Review 34, no. 4 (2010): 388-428.

- "Stalwart Giants: Medical Cosmopolitanism, Canadian Authorship, and American Publishers." Book History 12 (2009): 210-39. 
- "Writing Medicine: George M. Gould and Medical Print Culture in Progressive America." In Science in Print: Essays on the History of Science and the Culture of Print, edited by Rima D. Apple, Gregory J. Downey, and Stephen L. Vaughn, 10729. Madison: University of Wisconsin Press, 2012.

Cook, Harold J. Matters of Exchange: Commerce, Medicine, and Science in the Dutch Golden Age. New Haven, CT: Yale University Press, 2007.

Crawford, Susan. "Health Science Libraries in the United States: I. Overview of the Post-World War II Years." Bulletin of the Medical Library Association 71, no. 1 (1983): $16-20$.

. "Health Sciences Libraries of Professional Societies, Voluntary Health Organizations, and Foundations." Bulletin of the Medical Library Association 60, no. 2 Suppl. (1972): 38-45.

Crawford, Susan, Carol Michel, and Conrad Waligorski. "The Contemporary Medical Society Library." Bulletin of the Medical Library Association 53, no. 2 (1965): 178-95.

Darnton, Robert. "What Is the History of Books?" Daedalus 111 (Summer 1982): 65-83.

- "What is the History of Books?' Revisited." Modern Intellectual History 4, no. 3 (2007): 495-508.

Fyfe, Aileen. "Journals, Learned Societies and Money: Philosophical Transactions, ca. 1750-1900." Royal Society Notes and Records 69 (September 2015): 277-99.

Fyfe, Aileen, Julie McDougall-Waters, and Noah Moxham. “350 Years of Scientific Periodicals.” Royal Society Notes and Records 69 (September 2015): 227-39.

Gibson, Sarah S. "Scientific Societies and Exchange: A Facet of the History of Scientific Communication.” Journal of Library History 17, no. 2 (1982): 144-63.

Gwinn, Nancy E. "The Library of Congress, the Smithsonian Institution, and the Global Exchange of Government Documents, 1834-1889." Libraries and the Cultural Record 45, no. 1 (2010): 107-11.

-. "Smithsonian Institution Libraries, Washington, D.C., USA." In Encyclopedia of Library History, edited by Wayne A. Wiegand and Donald G. Davis, Jr., 578-80. New York: Garland, 1994.

Gwyn, Norman B. "Sir William Osler's Contributions to the Library of the Academy of Medicine, Toronto." Bulletin of the Academy of Medicine, Toronto 20 (1947): 266-71. 
Hanson, Elizabeth I. "Interlibrary Cooperation." In Encyclopedia of Library History, edited by Wayne A. Wiegand and Donald G. Davis, Jr., 285-87. New York: Garland, 1994.

Howsam, Leslie. Old Books and New Histories: An Orientation to Studies in Book and Print Culture. Toronto: University of Toronto Press, 2006.

- Past into Print: The Publishing of History in Britain, 1850-1950. London: British Library and University of Toronto, 2009.

- "The Study of Book History." In The Cambridge Companion to the History of the Book, edited by Leslie Howsam, 1-13. Cambridge: Cambridge University Press, 2015.

Jackson, H.J. Marginalia: Readers Writing in Books. New Haven, CT: Yale University Press, 2002.

Johns, Adrian. The Nature of the Book: Print and Knowledge in the Making. Chicago: University of Chicago Press, 1998.

Jones, Anne Hudson, and Faith McLellan, eds. Ethical Issues in Biomedical Publication. Baltimore: Johns Hopkins University Press, 2000.

Lamonde, Yvan, Patricia Lockhart Fleming, and Fiona A. Black, eds. History of the Book in Canada Volume Two 1840-1918. Toronto: University of Toronto Press, 2005.

Lilja, Johanna. "Developing the International Distribution of Humanities Studies in Finland: The Exchange of Publications of Two Learned Societies in 1831-1914." Library History 23 (September 2007): 213-21.

- "History of the International Exchange of Publications." In Handbook on the International Exchange of Publications, edited by Kirsti Ekonen, Païvi Paloposki, and Pentti Vattulainen, 49-68. München: K.G. Saur, 2006.

Love, Harold. "Early Modern Print Culture: Assessing the Models." In The Book History Reader, $2^{\text {nd }}$ ed., edited by David Finkelstein and Alistair McCleery, 74-86. London: Routledge, 2006.

MacDonald, Bertrum H. "Crossing Borders: The Smithsonian Institution and Nineteenth-century Diffusion of Scientific Information Between the United States and Canada." In Science in Print: Essays on the History of Science and the Culture of Print, edited by Rima D. Apple, Gregory J. Downey, and Stephen L. Vaughn, 87-106. Madison: University of Wisconsin Press, 2012. . and Jennifer J. Connor. "Science, Technology, and Medicine: Constructing 
Authorship." In History of the Book in Canada Volume Two 1840-1918, edited by Yvan Lamonde, Patricia Lockhart Fleming, and Fiona A. Black, 177-86. Toronto: University of Toronto Press, 2005.

Macdonald, Simon. "Transnational History: A Review of Past and Present Scholarship" (January 2013). University College London, Centre for Transnational History, https://www.ucl.ac.uk/centre-transnationalhistory/objectives/simon macdonald tns review.

Miksa, Francis L. "Classification.” In Encyclopedia of Library History, edited by Wayne A. Wiegand and Donald G. Davis, Jr., 144-53. New York: Garland, 1994.

Miles, Wyndham D. A History of the National Library of Medicine: The Nation's Treasury of Medical Knowledge. Bethesda, MD: National Library of Medicine, 1982.

Ngai, Mae M. "Promises and Perils of Transnational History." (December 2012), https://www.historians.org/publications-and-directories/perspectives-onhistory/december-2012/the-future-of-the-discipline/promises-and-perils-oftransnational-history.

Overmier, Judith A., and Lilli Sentz, "Medical Rare Book Provenance." Bulletin of the Medical Library Association 75, no. 1 (1987): 14-18.

Pearson, David. Provenance Research in Book History: A Handbook. London: British Library, 1994.

Peitzman, Steven J. A New and Untried Course: Woman's Medical College and Medical College of Pennsylvania, 1850-1998. New Brunswick, NJ: Rutgers University Press, 2000 .

Phelps, C. Deirdre. "Where's the Book? The Text in the Development of Literary Sociology.” TEXT: An Interdisciplinary Annual of Textual Studies 9 (1996): 63-92.

Raven, James. The Business of Books: Booksellers and the English Book Trade, 1450-1850. New Haven, CT: Yale University Press, 2007.

Rhode, Michael G., and James T.H. Connor. "“A Repository for Bottled Monsters and Medical Curiosities': The Evolution of the Army Medical Museum." In Defining Memory: Local Museums and the Construction of History in America's Changing Communities, $2^{\text {nd }}$ ed., edited by Amy K. Levin and Joshua G. Adair, 175-92. Lanham, MD: Rowman \& Littlefield, 2017.

Ryerson, E. Stanley. "Events Leading to the Formation of an Academy." Bulletin of the Academy of Medicine, Toronto 20 (1947): 231-38. 
Secord, James A. Victorian Sensation: The Extraordinary Publication, Reception, and Secret Authorship of Vestiges of the Natural History of Creation. Chicago: University of Chicago Press, 2000.

Sharpe, Kevin. Reading Revolutions: The Politics of Reading in Early Modern England. New Haven, CT: Yale University Press, 2000.

Shep, Sydney. "Books in Global Perspectives." In The Cambridge Companion to the History of the Book, edited by Leslie Howsam, 53-70. Cambridge: Cambridge University Press, 2015.

Stevens, Norman D. "Dana, John Cotton (1856-1929)." Dictionary of American Library Biography, edited by Bohdan S. Wynar, 115-20. Littleton, CO: Libraries Unlimited, 1978.

Walsh, Mary Roth. Doctors Wanted, No Women Need Apply: Sexual Barriers in the Medical Profession, 1835-1975. New Haven, CT: Yale University Press, 1977.

Young, Matthew McLennan. The Rise and Fall of the Printers' International Specimen Exchange. New Castle, DE: Oak Knoll Press, 2012. 